\title{
Antimicrobial Activity of Leaf Extracts of Memecylon heyneanum Benth. ex Wight \& Arn.: An Endemic Tree Species of Southern Western Ghats
}

\author{
Manikandan G. ${ }^{1, *}$, Ramasubbu R. ${ }^{2}$ \\ ${ }^{1}$ Department of Botany, Sri Kaliswari College (Autonomous), Sivakasi, Tamil Nadu, India \\ ${ }^{2}$ Department of Biology, The Gandhigram Rural Institute (Deemed to be University), Dindigul, Tamil Nadu, India
}

Received December 30, 2019; Revised March 11, 2020; Accepted March 19, 2020

Copyright $\odot 2020$ by authors, all rights reserved. Authors agree that this article remains permanently open access under the terms of the Creative Commons Attribution License 4.0 International License

\begin{abstract}
The genus Memecylon L. consists of more than 300 taxa, distributed mainly in the Old World. In Peninsular India, the genus Memecylon includes 34 species and nearly 18 species are endemic to the Western Ghats. Memecylon heyneayanum is an endemic and endangered tree species of Southern Western Ghats belonging to the family Melastomataceae, which is locally known as Kannavu, Kaya and Kanalai. It is a small tree growing in evergreen forests between the altitudes of 1500-2300 m asl. Being a medicinally promising species, the leaves of this evergreen tree are used to cure various ailments like diabetes, cough, leucorrhoea and menorrhagia. The powdered leaf was successively extracted with various solvents, Hexane, Petroleum ether, Chloroform, Acetone and Methanol through soxhlet apparatus. The extracts were tested for the antimicrobial activities against Bacillus cereus, Klebsiella pneumonia, Micrococcus mucilaginosus, Pseudomonas aeruginosa, Staphylococcus aureus, Klebsiella terrigena, E. coli, Candida glabrata, Candida albicans and Candida sp. by agar well diffusion method at various concentrations $(100 \mu \mathrm{g}, 150 \mu \mathrm{g}$ and $200 \mu \mathrm{g}$ ) of extracts. All the extracts were effectively tested against microorganisms and also compared with standard antibiotic (Ampicilin; 100mg/ml). The maximum antimicrobial activities were obtained with maximum zone of inhibition in methanol $(200 \mu \mathrm{g})$ extract followed by Acetone, Chloroform, Petroleum ether and Hexane. The current results indicated that the potentiality of methanolic leaf extract and this can be utilized as natural drug for the treatment of several infectious diseases by microorganisms.
\end{abstract}

Keywords Memecylon, Antimicrobial, Methanol, Microorganisms, Ampicillin

\section{Introduction}

Nature has been a source of medicine for thousands of years and an impressive number of modern drugs have been derived from natural sources, many of these isolations were based on the uses of the agents in traditional medicine [1]. The importance of medicinal plants and traditional health systems in solving the health care problem of the world is gaining attention. Because of this resurgence of interest, the research on plants of medicinal importance is growing phenomenally at the international level, often to the detriment of natural habitats and mother populations in the countries of origin. Most of the developing countries have adopted traditional medicinal practice as an integral part of their culture. Historically, all medicinal preparations are derived from plants, whether in the simple from of taw plants materials or in the refined from of crude extracts, mixtures etc. [2]

World Health Organization [3] estimated that 4 billion people, $80 \%$ of world population presently use herbal medicine for some aspects of primary health care. Herbal medicine is a major component in all indigenous people. Traditional medicine and common element in Ayurvedic, Homeopathic, Naturopathic and traditional oriented. WHO stated that of 119 plants derived pharmaceutical medicine, about $74 \%$ are used in modern medicine in way that correlated directly with their traditional uses and demand of medicinal plants in goes on increasing developing and developed countries.

The use of plants and plant products as medicines could be traced as far back as the beginning of human civilization. The earliest mention of medicinal use of plants in Hindu culture is found in 'Rigveda' which is said to have been written between 4500-1600B.C and is supposed to be the oldest repository of human knowledge [4]. Man has been dependent on plants from the time immemorial for food, 
fodder, clothes, medicines etc. The existence of medicinal value in plants was well understood by ancient mankind. Since the dawn of civilization, the science of ayurvedha, unani system of medicine and homeopathy are based on plants or plant products. Plants have been an essential plant of human society since the start of civilization. During the vedic period great importance was given to plants Rigveda and Atharvanaveda described medicinal plants. Around 250 drugs have been identified from such descriptions [5].

The phytochemical analysis of tribal medicinal plants will help in determining the action of medicines. The chemical composition of a drug is not infrequently the key to its pharmacological action. The efficacy of a plant drug depends on the total effect of the plant contents. The rapid disappearance of some wonderful tribal medicinal plants due to over exploitation and continuous extraction has led to a realization of the urgent need for production of such medicinal plant [6].

Many efforts have been made to discover new antimicrobial compounds from various kinds of sources such as microorganisms, animals and plants, one of such resources of folk medicines. Systematic screening of them may result on discovery of novel effective compounds. The increasing prevalence of multidrug resistant strains of antibiotics raises the specter of untreatable bacterial infections and adds urgency to the search for new infections fighting strategies [7].

The genus Memecylon L. belongs to the family Melastomataceae and encompasses about 250 species of shrubs and trees. The species are distributed worldwide in various types of habitats such as deciduous, semi-evergreen, evergreen and other forests with a wide range of altitude from sea level. In India, about 39 species of Memecylonare reported of which 21 are endemic to the country and the Western Ghats are known to host 32 species. The members of the genus Memecylon are shown to possess several biological activities such as antioxidant, antimicrobial, antipsoriatic, enzyme inhibitory, anthelmintic, antidiabetic, anti-inflammatory, analgesic, wound healing [8]. The literature survey reveals that the leaves and roots of Memecylon umbellatum have been investigated for its hypoglycemic activity using alloxan induced hyperglycemia Wistar albino rats. Wound healing activity of ethanolic extract of the leaves has also been reported [9]. But literature on overall antimicrobial efficiency of Memecylon heyneayanum is not reported elsewhere. In this connection, a study has been framed to analyze the antimicrobial potentialities of leaf extracts of Memecylon heyneyanum.

\section{Materials and Methods}

\subsection{Collection of Plant Materials}

The plant Memecylon heyneayanum leaves were collected from Courtalam, hills Thirunelveli dist., Tamil Nadu, India (Plate 1). The leaves were washed thoroughly three times with purified water and once with distilled water. The plant materials were completely air-dried at room temperature for 3 weeks and then powdered by using electric blender to get a fine powder. The powdered samples were kept in sealed air tight containers for the extraction of active chemicals.

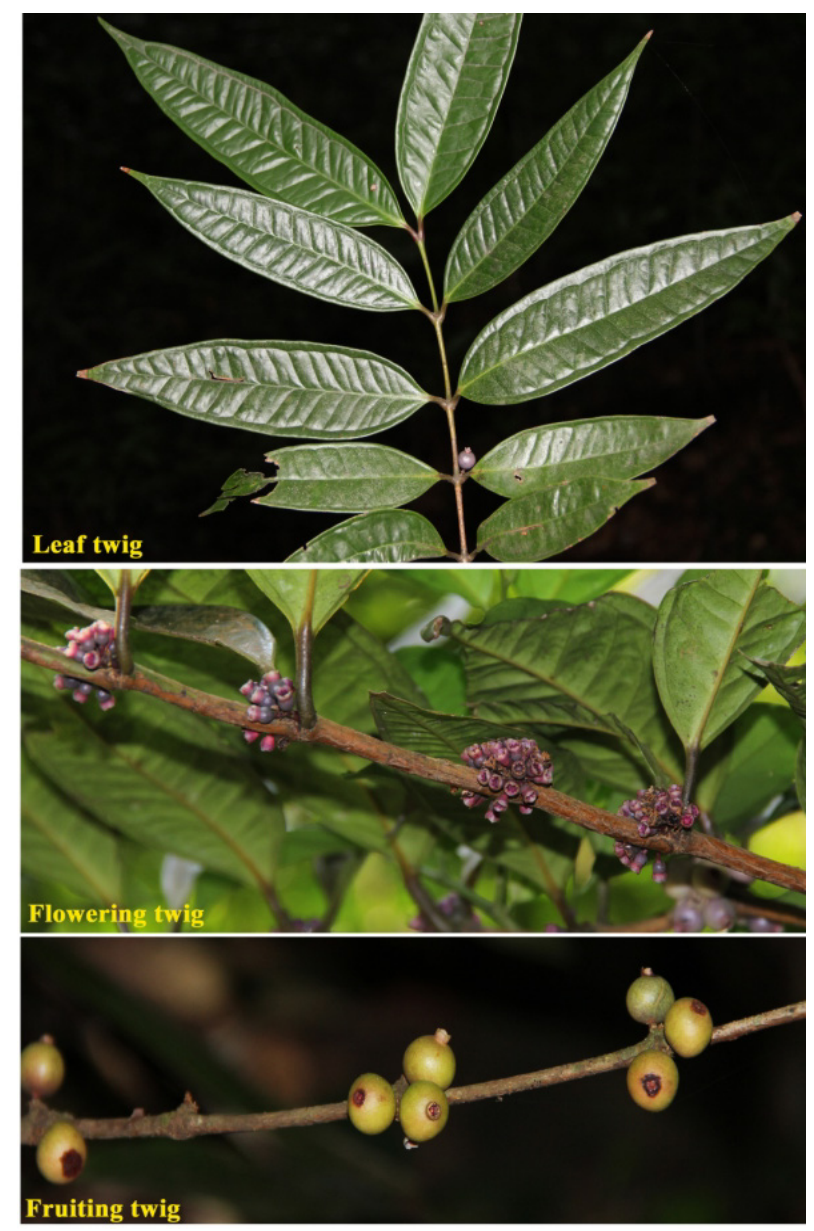

Plate 1. Memecylon heyneayanum

\subsection{Preparation of Plant Extract}

The extraction procedures were continued for $4-8 \mathrm{hr}$ at $60^{\circ} \mathrm{C}$. The powered sample $(50 \mathrm{~g})$ of $M$. heyneayanum was successively extracted with $200 \mathrm{ml}$ of solvent Hexane followed by Petroleum ether, Chloroform, Acetone and Methanol. Every time before with the next solvent the plant material was dried in a air oven below $5^{\circ} \mathrm{C}$ and these extracts were concentrated at $40^{\circ} \mathrm{c}$ under reduced used pressure $(72 \mathrm{~m})$ with a rotary evaporator and dried using lyophilizer. Dried extract was collected in air tight container and store in $4^{\circ} \mathrm{C}$ for future use [10].

\subsection{Determination of Antimicrobial Activities}

Agar well-diffusion method was followed to determine 
the antimicrobial activity. Nutrient agar (NA) and Potato Dextrose Agar (PDA) plates were spreaded with the help of L-rod inside the laminar air flow chamber with 8 hours old broth culture of respective bacteria and fungi (Table 1). Wells with $6 \mathrm{~mm}$ diameter and about $2 \mathrm{~cm}$ a part were made in a medium of petriplate each using sterile cork borer. Stock solution of each plant extract was prepared at a concentration of 100,150 and $200 \mu \mathrm{g} / \mathrm{ml}$ from different solvents viz. Hexane, Petroleum ether, Chloroform, Acetone and Methanol. The extracts were added with the help of sterile syringe into the wells and allowed to diffuse at room temperature for $2 \mathrm{hrs}$. Standard antibiotic, Ampicillin was $(100 \mathrm{mg} / \mathrm{ml})$ selected to serve as positive control. Control experiments comprising inoculums without plant extract were set up and the plates were incubated at $37^{\circ} \mathrm{C}$ for $18-24 \mathrm{~h}$ for bacterial pathogens and $28^{\circ} \mathrm{C}$ for 48 hours for fungal pathogens. The diameter of the inhibition zone ( $\mathrm{mm}$ ) was measured by Antibiotic scale (Himedia) and the activity index was also calculated for triplicates of each experiment.

Table 1. Standard microbial strains used for screening of antimicrobial activities of Memecylon heyneayanum

\begin{tabular}{|c|c|c|}
\hline S.No & Name of the microbial strain & Grams nature \\
\hline 1 & Bacillus cereus & Gram-positive bacteria \\
\hline 2 & Staphylococcus aureus & Gram-positive bacteria \\
\hline 3 & Micrococcus mucilaginosus & Gram-positive bacteria \\
\hline 4 & Klebsiella pneumoniae & Gram-negative bacteria \\
\hline 5 & Pseudomonas aeruginosa & Gram-negative bacteria \\
\hline 6 & Escherichia coli & Gram-negative bacteria \\
\hline 7 & Klebsiella terrigena & Gram-negative bacteria \\
\hline 9 & Candida albicans & Fungi \\
\hline 10 & Candida glabrata & Fungi \\
\hline
\end{tabular}

\section{Results and Discussion}

The traditional methods, especially the usage of medicinal plants, still play a vital role to cover the basic health needs in the developing countries and moreover, the use of herbal remedies has risen in the developed countries in the last decade. Plants have provided a source of inspiration of novel drug compounds, as plant derived medicines have made large contributions to human health and well-being. Their role is twofold namely; they provide key chemical structure for the development of new antimicrobial drugs and also as a phytomedicine to be used for the treatment of disease. Diffusion method is extensively used to investigate the antimicrobial activity of natural substances and plant extracts. These assays are based on the use of discs or holes as reservoirs containing the solutions of substances to be examined [11].

Emergence of multi-drug resistance in human and animal pathogenic bacteria as well as undesirable side effects of certain antibiotics has triggered immense interest in the search for new antimicrobial drugs from plants. In the present study antimicrobial activity for the leaf extracts of Memecylon heyneayanum was tested using the agar-well diffusion method with selected microorganisms. Gram-positive bacteria viz.Bacillus cereus, Staphylococcus aureus, Micrococcus mucilaginosus and gram-negative bacteria, Klebsiella pneumoniae, Pseudomonas aeuruginosa, Escherichia coli, and Klebsiella terrigena and fungal species Candida albicans, Candida glabrata and Candida sp. Were studied the leaf extracts showed antimicrobial potential against gram-positive, gramnegative bacteria and also with few pathogenic fungi. The results indicated that the leaf extracts might be used as natural drug for the treatment of several infectious diseases caused by these organisms and could be useful in understanding the relations between traditional cures and current medications.

The results of the hexane, petroleum ether, chloroform, acetone and methanol extracts of Memecylon heyneayanum leaves exhibited antimicrobial activity against all the tested microbial strains. The zones of inhibitions were produced bythe hexane, petroleum ether, chloroform, acetone and methanol extracts against all thetest organisms. Among these three concentrations $(100 \mu \mathrm{g} / \mathrm{ml}, 150 \mu \mathrm{g} / \mathrm{ml}$ and 200 $\mu \mathrm{g} / \mathrm{ml}$ ) of methanolic extract studied the higher concentration $(200 \mu \mathrm{g} / \mathrm{ml})$ showed more activethan the selected solvents followed by acetone, chloroform, petroleum ether and hexane extracts. In addition, the inhibition zones formed by standard antibiotics ampicillin $(100 \mathrm{mg} / \mathrm{ml})$ and those of negative controls are recorded.

The highest zone ofinhibitions $(21 \pm 1.76 \mathrm{~mm})$ was noticed in methanol leaf extracts of Memecylon heyneayanum against Escherichia coli. The zones of inhibition were rangingfrom $21 \pm 1.76-18 \pm 1.51 \mathrm{~mm}$ in diameter in Escherichia coli followed by Candida sp., Micrococcus mucilaginosus, Pseudomonas aeuruginosa, Staphylococcus aureus, Candida albicans, Klebsiella terrigena, Klebsiella pneumoniae, Candida glabrata and Bacillus cereus in $200 \mu \mathrm{g} / \mathrm{ml}$ concentration (Table 2; Plate 2).

The highest zone of inhibitions $(19.10 \pm 1.52 \mathrm{~mm})$ was recorded in acetone leaf extract of Memecylon heyneayanum against Candida albicans. The zones of inhibition ranging from $19.10 \pm 1.526-14.66 \pm 1.32 \mathrm{~mm}$ in diameter in Candida albicans followed by Candida sp., Escherichia coli, Pseudomonas aeuruginosa, Candida glabrata, Klebsiella terrigena, Klebsiella pneumoniae, Micrococcus mucilaginosus, Bacillus cereus and Staphylococcus aureus in $200 \mu \mathrm{g} / \mathrm{ml}$ concentration (Table 3; Plate 3). The maximum zone of inhibitions $(18.33 \pm 1.50$ 
$\mathrm{mm}$ ) recorded in chloroform leaf extract of Memecylon heyneayanum against Escherichia coli. The zones of inhibition ranging from $18.33 \pm 1.50-13.33 \pm 1.71 \mathrm{~mm}$ in diameter in Escherichia coli followed by Candida glabrata, Staphylococcus aureus, Pseudomonas aeuruginosa, Bacillus cereus, Candida albicans, Klebsiella pneumoniae, Klebsiella terrigena, Candida sp. and Micrococcus mucilaginosus in $200 \mu \mathrm{g} / \mathrm{ml}$ concentration (Table 4; Plate 4).

The petroleum etherleaf extract $(200 \mu \mathrm{g} / \mathrm{ml})$ of Memecylon heyneayanum showed (Table 5; Plate 5) higher zone of inhibition $(15.57 \pm 1.08 \mathrm{~mm}-13.01 \pm 1.69 \mathrm{~mm})$ against Klebsiella pneumonia followed by Candida albicans, Micrococcus mucilaginosus, Pseudomonas aeuruginosa, Escherichia coli, Candida sp., Staphylococcus aureus, Candida glabrata, Bacillus cereus and Klebsiella terrigena. The hexaneleaf extract (200 $\mu \mathrm{g} / \mathrm{ml}$ ) of Memecylon heyneayanum showed higher zone of inhibition (14.59 $\pm 1.21 \mathrm{~mm}-10.94 \pm 1.04 \mathrm{~mm})$ against Candida glabrata followed by Klebsiellaterrigena, Escherichia coli, Staphylococcus aureus, Klebsiella pneumonia, Pseudomonas aeuruginosa, Candida sp., Bacillus cereus, Candida albicans, and Micrococcus mucilaginosus (Table 6; Plate 6).

Table 2. Effect of Methanol leaf extracts of Memecylon heyneayanum on zone of inhibition on selected pathogenic microorganisms

\begin{tabular}{|c|c|c|c|c|c|c|}
\hline \multirow{3}{*}{ S.No } & \multirow{3}{*}{ Name of the microbial strains } & \multicolumn{5}{|c|}{ Zone of inhibition(mm) } \\
\hline & & \multicolumn{4}{|c|}{ Methanol $(\mu \mathrm{g} / \mathrm{ml})$} & \multirow{2}{*}{$\begin{array}{l}\text { Ampicillin } \\
100 \mathrm{mg} / \mathrm{ml}\end{array}$} \\
\hline & & 100 & 150 & 200 & Control & \\
\hline 1. & Bacillus cereus & $13 \pm 1.04$ & $15.5 \pm 0.5$ & $18 \pm 1.51$ & $6 \pm 0.81$ & $20 \pm 0.95$ \\
\hline 2. & Staphylococcus aureus & $13 \pm 1.37$ & $15 \pm 0.50$ & $20 \pm 1.78$ & $7 \pm 0.81$ & $20 \pm 0.57$ \\
\hline 3. & Klebsiella pneumonia & $10.5 \pm 0.58$ & $16.5 \pm 0.70$ & $19 \pm 1.39$ & $7 \pm 0.57$ & $21 \pm 0.50$ \\
\hline 4. & Micrococcus mucilaginosus & $13 \pm 1.81$ & $18.5 \pm 0.5$ & $21 \pm 1.23$ & $5 \pm 0.50$ & $21 \pm 0.81$ \\
\hline 5. & Pseudomonas aeruginosa & $11.5 \pm 0.85$ & $15.5 \pm 0.51$ & $20 \pm 0.98$ & $5 \pm 0.95$ & $21 \pm 0.95$ \\
\hline 6. & Escherichia coli & $12 \pm 1.21$ & $16 \pm 1.58$ & $21 \pm 1.76$ & $5 \pm 0.57$ & $21 \pm 0.81$ \\
\hline 7. & Klebsiellaterrigena & $11.5 \pm 1.54$ & $17 \pm 1.59$ & $19 \pm 1.90$ & $5 \pm 0.81$ & $21 \pm 0.81$ \\
\hline 8. & Candida albicans & $10.5 \pm 0.36$ & $16.5 \pm 0.78$ & $19.5 \pm 0.91$ & $6 \pm 0.81$ & $21 \pm 0.57$ \\
\hline 9. & Candida glabrata & $11.5 \pm 0.58$ & $15 \pm 0.60$ & $18 \pm 2$ & $6 \pm 1.98$ & $21 \pm 1.50$ \\
\hline 10. & Candida sp. & $11.5 . \pm 0.70$ & $18 \pm 1.32$ & $21.5 \pm 1.51$ & $7 \pm 0.57$ & $20 \pm 1.29$ \\
\hline
\end{tabular}

\pm - standard error 


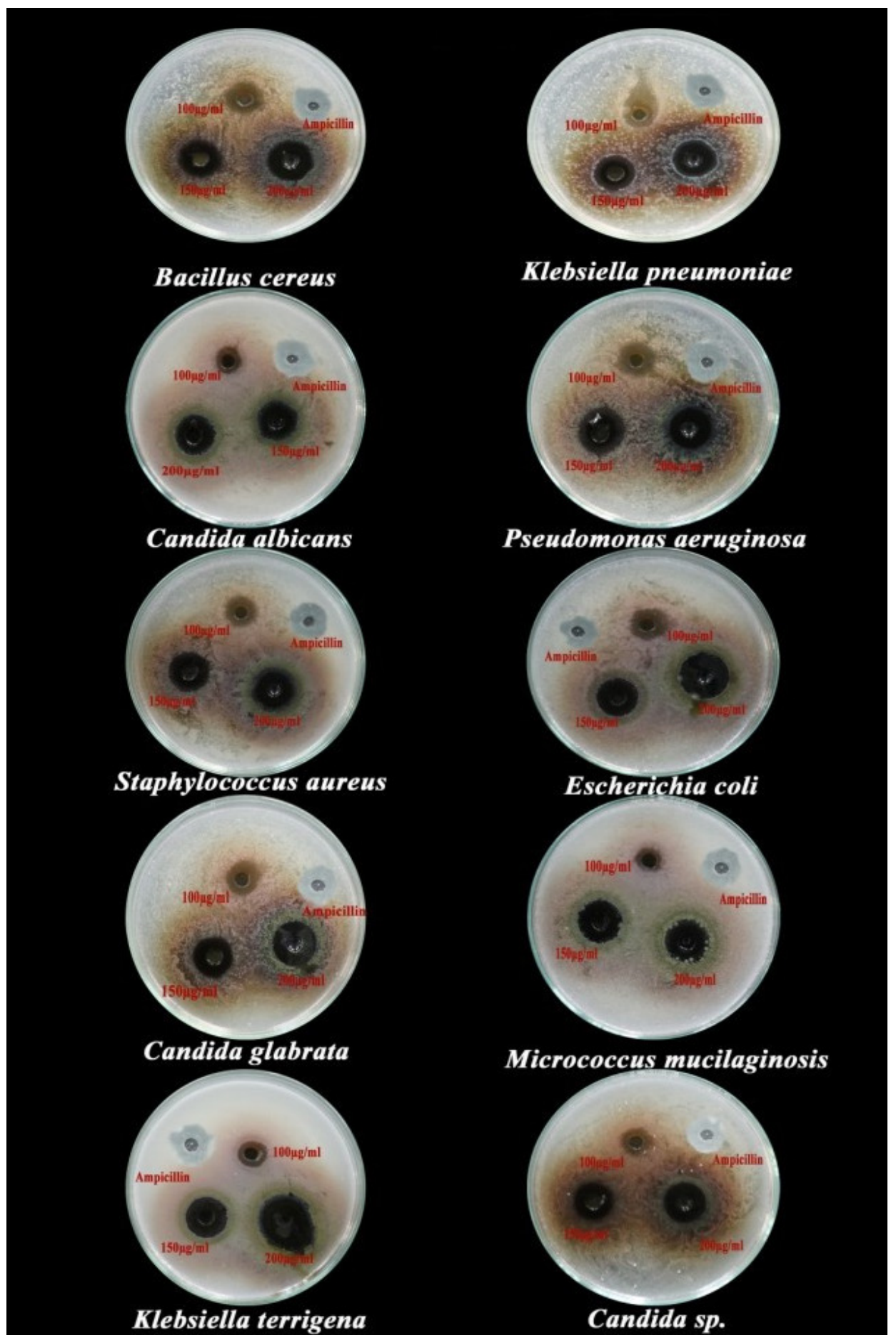

Plate 2. Antimicrobial activity of Methanolic leaf extracts against human pathogens 
Table 3. Effect of Acetone leaf extracts of Memecylon heyneayanum on zone of inhibition on selected pathogenic microorganism

\begin{tabular}{|c|c|c|c|c|c|c|}
\hline \multirow{3}{*}{ S.No } & \multirow{3}{*}{ Name of the microbial strains } & \multicolumn{5}{|c|}{ Zone of inhibition(mm) } \\
\hline & & \multicolumn{4}{|c|}{ Acetone $(\mu \mathrm{g} / \mathrm{ml})$} & \multirow{2}{*}{$\begin{array}{l}\text { Ampicillin } \\
100 \mathrm{mg} / \mathrm{ml}\end{array}$} \\
\hline & & 100 & 150 & 200 & Control & \\
\hline 1. & Bacillus cereus & $10 \pm 1.71$ & $11.33 \pm 1.52$ & $15 \pm 1$ & $7 \pm 1.03$ & $20 \pm 0.95$ \\
\hline 2. & Staphylococcus aureus & $8.66 \pm 1.15$ & $10 \pm 0.83$ & $14.66 \pm 1.52$ & $5 \pm 1.63$ & $20 \pm 0.57$ \\
\hline 3. & Klebsiella pneumonia & $11.33 \pm 1.52$ & $12 \pm 1.73$ & $17 \pm 1.70$ & $7 \pm 2.07$ & $21 \pm 0.50$ \\
\hline 4. & Micrococcus mucilaginosus & $10 \pm 1.25$ & $11.33 \pm 0.57$ & $14 \pm 2.17$ & $6 \pm 1.82$ & $21 \pm 0.81$ \\
\hline 5. & Pseudomonas aeruginosa & $11 \pm 1.31$ & $12 \pm 1.73$ & $15.33 \pm 0.57$ & $7 \pm 2.03$ & $21 \pm 0.95$ \\
\hline 6. & Escherichia coli & $10.66 \pm 1.5$ & $12.66 \pm 1.15$ & $15.33 \pm 0.57$ & $6 \pm 0.38$ & $21 \pm 0.81$ \\
\hline 7. & Klebsiellaterrigena & $11.33 \pm 1.52$ & $12.66 \pm 1.52$ & $15.66 \pm 2.08$ & $7 \pm 1.97$ & $21 \pm 0.81$ \\
\hline 8. & Candida albicans & $10.66 \pm 1.15$ & $13.33 \pm 2.08$ & $15.66 \pm 1.52$ & $6 \pm 1.31$ & $21 \pm 0.57$ \\
\hline 9. & Candida glabrata & $10.33 \pm 1.52$ & $12 \pm 1.01$ & $12 \pm 1.01$ & $8 \pm 2.30$ & $21 \pm 1.50$ \\
\hline 10. & Candida $\mathrm{sp}$. & $10 \pm 1.81$ & $13 \pm 1.17$ & $15.33 \pm 1.52$ & $5 \pm 1.51$ & $20 \pm 1.29$ \\
\hline
\end{tabular}

\pm - standard error

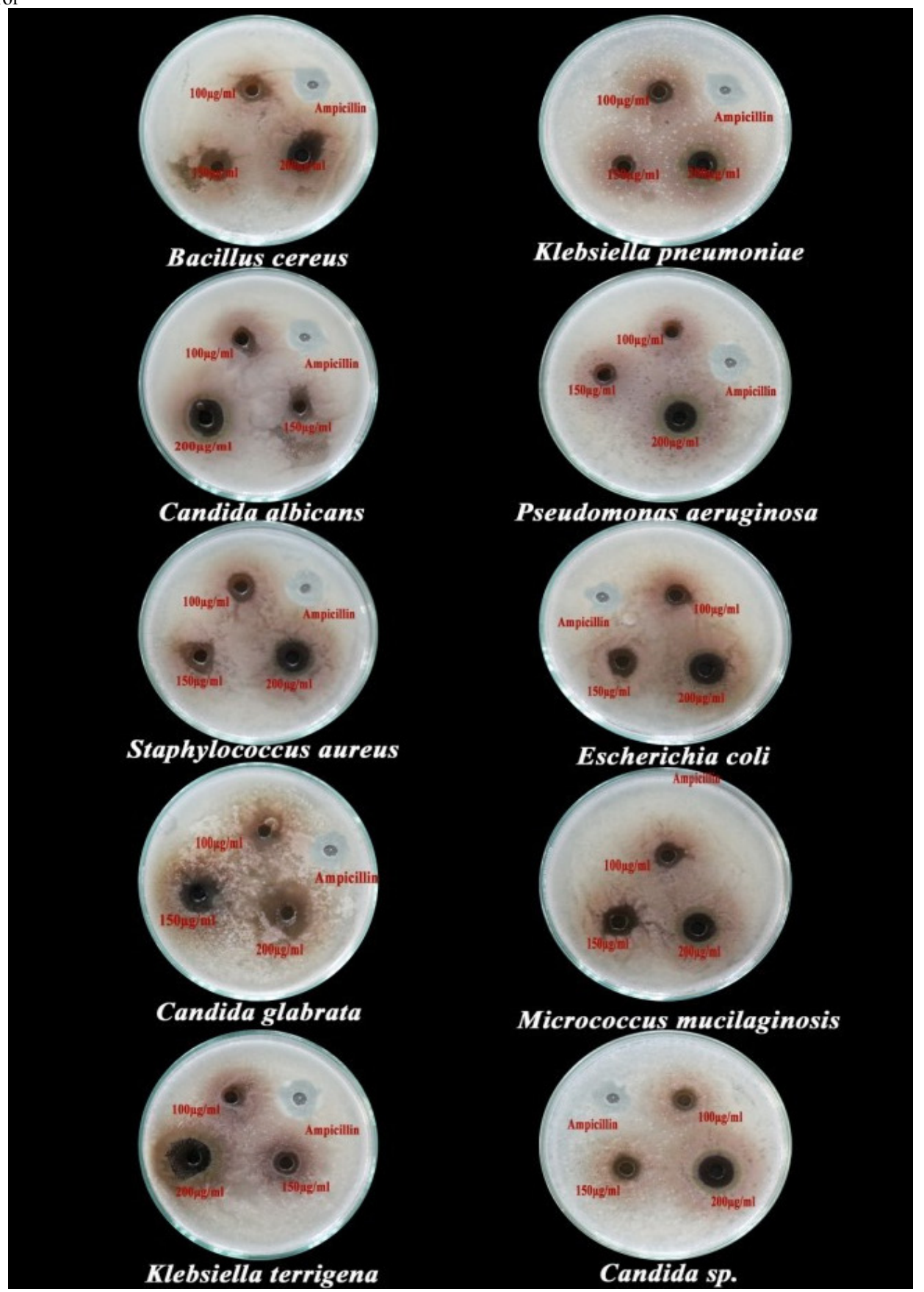

Plate 3. Antimicrobial activity of acetone leaf extracts against human pathogens 
Table 4. Effect of Chloroform leaf extracts of Memecylon heyneayanum on zone of inhibition on selected pathogenic microorganism

\begin{tabular}{|c|c|c|c|c|c|c|}
\hline \multirow{3}{*}{ S.No } & \multirow{3}{*}{ Name of the microbial strains } & \multicolumn{5}{|c|}{ Zone of inhibition $(\mathrm{mm})$} \\
\hline & & \multicolumn{4}{|c|}{ Chloroform $(\mu \mathrm{g} / \mathrm{ml})$} & \multirow{2}{*}{$\begin{array}{l}\text { Ampicillin } \\
100 \mathrm{mg} / \mathrm{ml}\end{array}$} \\
\hline & & 100 & 150 & 200 & Control & \\
\hline 1. & Bacillus cereus & $8.33 \pm 1.52$ & $10.66 \pm 1.15$ & $15.66 \pm 1.52$ & $6 \pm 0.50$ & $20 \pm 0.95$ \\
\hline 2. & Staphylococcus aureus & $9.33 \pm 1.52$ & $10.66 \pm 1.52$ & $14.66 \pm 1.15$ & $06 \pm 0.81$ & $20 \pm 0.57$ \\
\hline 3. & Klebsiella pneumonia & $10 \pm 1.74$ & $10.66 \pm 2.08$ & $13.66 \pm 1.52$ & $06 \pm 0.95$ & $21 \pm 0.50$ \\
\hline 4. & Micrococcus mucilaginosus & $7.66 \pm 1.51$ & $8.66 \pm 1.15$ & $13.33 \pm 1.52$ & $06 \pm 0.95$ & $21 \pm 0.81$ \\
\hline 5. & Pseudomonas aeruginosa & $10 \pm 1.37$ & $12.33 \pm 1.52$ & $16 \pm 2.01$ & $6 \pm 0.57$ & $21 \pm 0.95$ \\
\hline 6. & Escherichia coli & $10 \pm 1.64$ & $14.66 \pm 1.52$ & $20.33 \pm 1.50$ & $7 \pm 0.50$ & $21 \pm 0.81$ \\
\hline 7. & Klebsiellaterrigena & $8 \pm 3.60$ & $10.33 \pm 2.51$ & $14.66 \pm 2.08$ & $7 \pm 1.29$ & $21 \pm 0.81$ \\
\hline 8. & Candida albicans & $9 \pm 1.75$ & $12.66 \pm 1.52$ & $15.33 \pm 1.52$ & $4 \pm 0.81$ & $21 \pm 0.57$ \\
\hline 9. & Candida glabrata & $11.33 \pm 1.51$ & $13 \pm 1.73$ & $16.66 \pm 1.52$ & $8 \pm 0.57$ & $21 \pm 1.50$ \\
\hline 10. & Candida sp. & $9.33 \pm 1.08$ & $12.33 \pm 1.05$ & $14 \pm 1.97$ & $5 \pm 0.95$ & $20 \pm 1.29$ \\
\hline
\end{tabular}

\pm - standard error
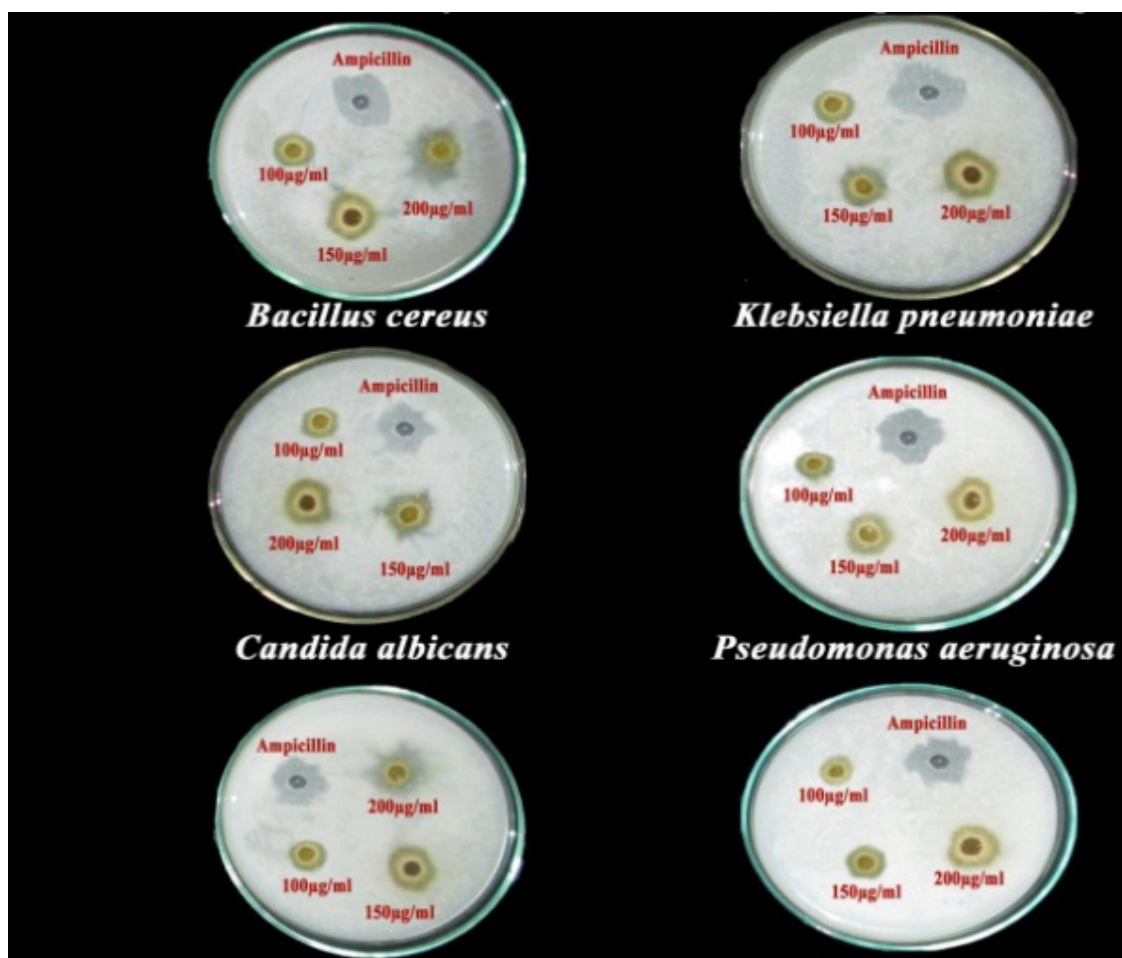

Staphylococcus aureus

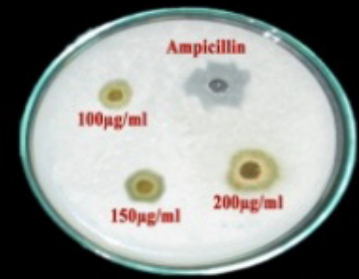

Escherichia coli
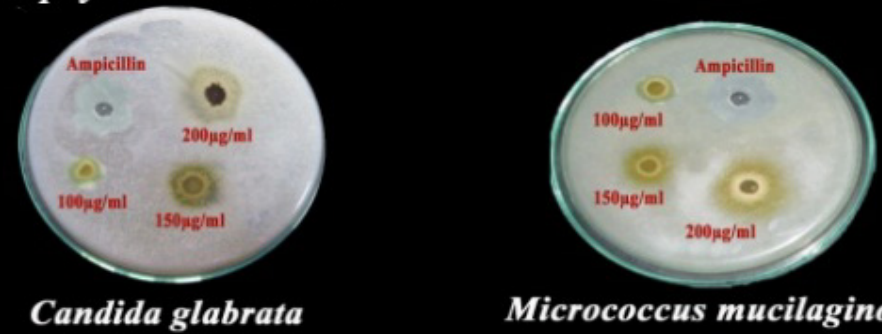

Micrococcus mucilaginosus
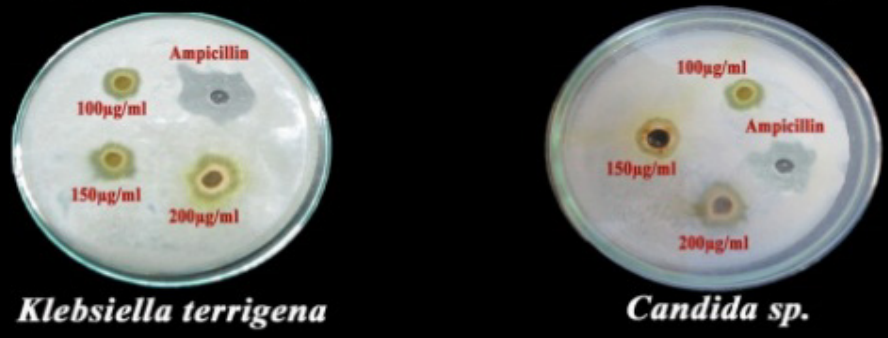

Plate 4. Antimicrobial activity of chloroform leaf extracts against human pathogens 
Table 5. Effect of Petroleum ether leaf extracts of Memecylon heyneayanum on zone of on inhibition selected pathogenic microorganism

\begin{tabular}{|c|c|c|c|c|c|c|}
\hline \multirow{2}{*}{ S.No } & \multirow{3}{*}{ Name of the microbial strains } & \multicolumn{5}{|c|}{ Zone of inhibition(mm) } \\
\cline { 3 - 7 } & & $\mathbf{1 0 0}$ & $\mathbf{1 5 0}$ & $\mathbf{2 0 0}$ & Control & $\mathbf{1 0 0} \mathbf{~ m g} / \mathbf{m l}$ \\
\cline { 3 - 7 } & & $8.03 \pm 1.18$ & $10.02 \pm 1.87$ & $13.07 \pm 1.84$ & $8 \pm 1.43$ & $20 \pm 0.95$ \\
\hline 1. & Bacillus cereus & $9.98 \pm 1.87$ & $11.79 \pm 1.42$ & $13.53 \pm 1.32$ & $8 \pm 1.90$ & $20 \pm 0.57$ \\
\hline 2. & Staphylococcus aureus & $9.43 \pm 1.93$ & $12.03 \pm 1.63$ & $15.57 \pm 1.08$ & $8 \pm 1.21$ & $21 \pm 0.50$ \\
\hline 3. & Klebsiella pneumonia & $10.42 \pm 2.98$ & $13.57 \pm 1.97$ & $15.14 \pm 1.90$ & $9 \pm 2.15$ & $21 \pm 0.81$ \\
\hline 4. & Micrococcus mucilaginosus & $9.80 \pm 1.75$ & $11.21 \pm 1.62$ & $14.89 \pm 1.00$ & $7 \pm 1.87$ & $21 \pm 0.95$ \\
\hline 5. & Pseudomonas aeruginosa & $11.01 \pm 2.07$ & $12.81 \pm 1.36$ & $14.72 \pm 1.26$ & $8 \pm 1.61$ & $21 \pm 0.81$ \\
\hline 6. & Escherichia coli & $9.49 \pm 1.41$ & $11.01 \pm 1.58$ & $13.01 \pm 1.69$ & $8 \pm 1.72$ & $21 \pm 0.81$ \\
\hline 7. & Klebsiellaterrigena & $10.00 \pm 1.37$ & $12.52 \pm 1.76$ & $15.48 \pm 1.25$ & $8 \pm 1.53$ & $21 \pm 0.57$ \\
\hline 8. & Candida albicans & $9.74 \pm 1.53$ & $11.00 \pm 1.73$ & $13.29 \pm 1.27$ & $9 \pm 1.05$ & $21 \pm 1.50$ \\
\hline 9. & Candida glabrata & $8.69 \pm 1.82$ & $10.25 \pm 0.11$ & $14.39 \pm 1.09$ & $9 \pm 1.84$ & $20 \pm 1.29$ \\
\hline 10. & Candida sp. & &
\end{tabular}

\pm - standard error

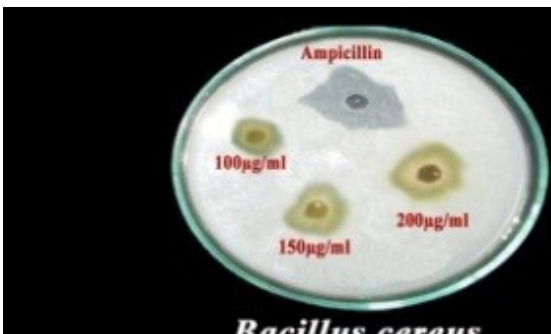

Bacillus cereus
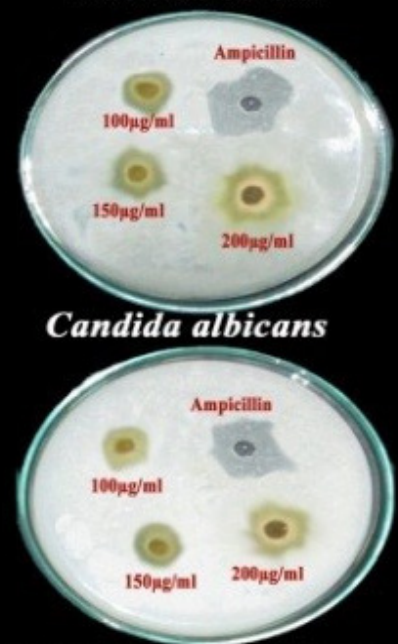

Staphylococcus aureus
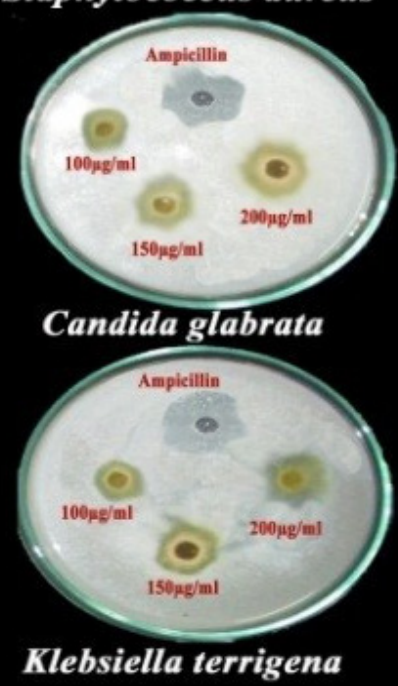

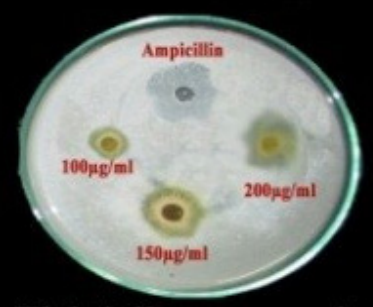

Klebsiella pneumoniae

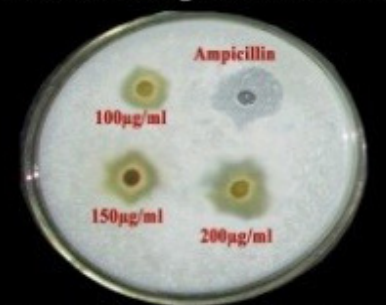

Pseudomonas aeruginosa

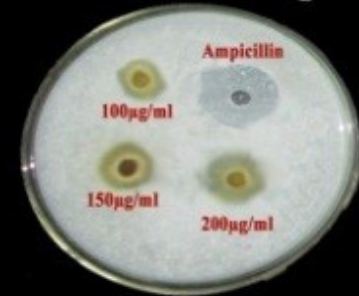

Escherichia coli

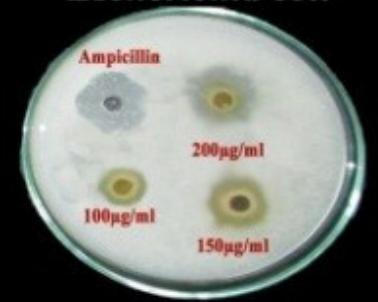

Micrococcus mucilaginosis

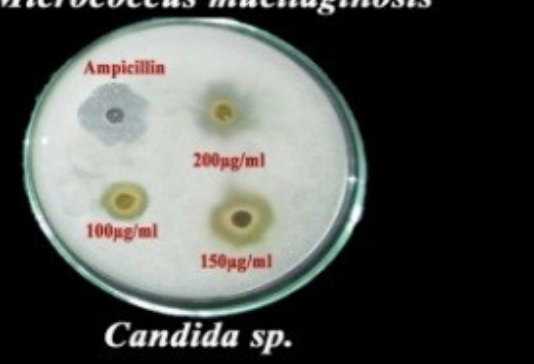

Plate 5. Antimicrobial activity of Petroleum leaf extracts against human pathogens 
Antimicrobial Activity of Leaf Extracts of Memecylon heyneanum Benth. ex Wight \& Arn.: An Endemic Tree Species of Southern Western Ghats

Table 6. Effect of Hexane leaf extracts of Memecylon heyneayanum on zone of inhibition selected on pathogenic microorganism

\begin{tabular}{|c|c|c|c|c|c|c|}
\hline \multirow{2}{*}{ S.No } & \multirow{3}{*}{ Name of the microbial strains } & \multicolumn{5}{|c|}{ Zone of inhibition $(\mathrm{mm})$} \\
\cline { 3 - 7 } & & 100 & 150 & 200 & Control & $100 \mathrm{mg} / \mathrm{ml}$ \\
\cline { 3 - 7 } & & $6.91 \pm 1.07$ & $8.26 \pm 1.05$ & $11.51 \pm 1.19$ & $6 \pm 0.02$ & $20 \pm 0.95$ \\
\hline 1. & Bacillus cereus & $7.13 \pm 1.43$ & $9.34 \pm 1.92$ & $12.61 \pm 1.90$ & $5 \pm 1.24$ & $20 \pm 0.57$ \\
\hline 2. & Staphylococcus aureus & $8.00 \pm 1.03$ & $9.46 \pm 1.30$ & $12.42 \pm 1.57$ & $5 \pm 1.82$ & $21 \pm 0.50$ \\
\hline 3. & Klebsiella pneumonia & $7.31 \pm 2.11$ & $8.12 \pm 1.00$ & $10.94 \pm 1.04$ & $6 \pm 2.35$ & $21 \pm 0.81$ \\
\hline 4. & Micrococcus mucilaginosus & $7.00 \pm 1.03$ & $9.87 \pm 1.91$ & $12.00 \pm 1.98$ & $6 \pm 1.32$ & $21 \pm 0.95$ \\
\hline 5. & Pseudomonas aeruginosa & $10 \pm 2.64$ & $12.36 \pm 1.02$ & $13.43 \pm 2.21$ & $7 \pm 0.34$ & $21 \pm 0.81$ \\
\hline 6. & Escherichia coli & $6.21 \pm 1.53$ & $8.21 \pm 1.01$ & $13.83 \pm 1.31$ & $6 \pm 0.31$ & $21 \pm 0.81$ \\
\hline 7. & Klebsiellaterrigena & $7.00 \pm 1.09$ & $9.08 \pm 1.12$ & $11.46 \pm 1.64$ & $5 \pm 1.73$ & $21 \pm 0.57$ \\
\hline 8. & Candida albicans & $9.13 \pm 2.01$ & $11 \pm 1.00$ & $14.59 \pm 1.21$ & $6 \pm 0.63$ & $21 \pm 1.50$ \\
\hline 9. & Candida glabrata & $7.38 \pm 1.28$ & $9.58 \pm 2.41$ & $12.00 \pm 2.00$ & $7 \pm 1.41$ & $20 \pm 1.29$ \\
\hline 10. & Candida sp. & & &
\end{tabular}

\pm - standard error

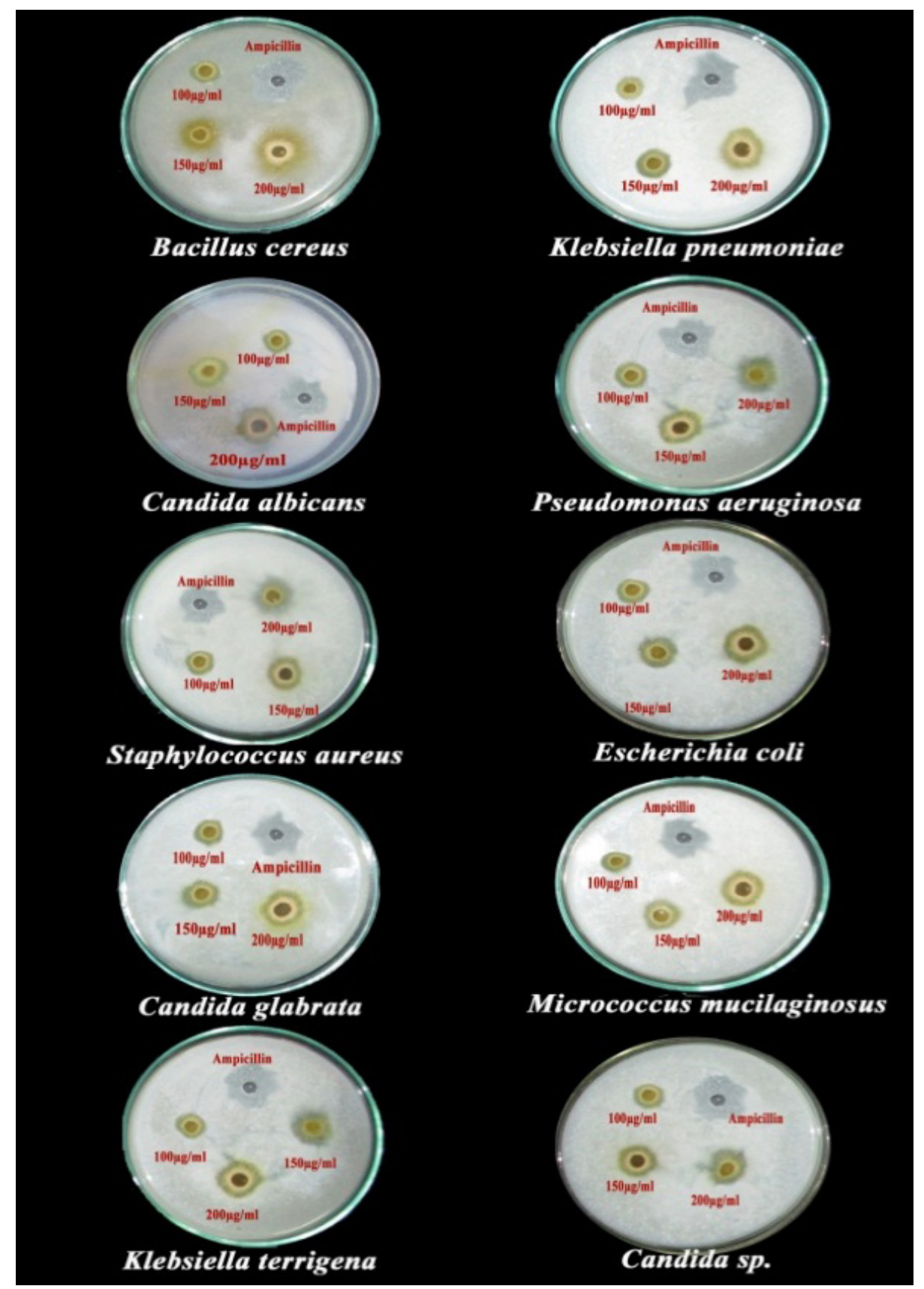

Plate 6. Antimicrobial activity of hexane leaf extracts against human pathogens 
In the present study, hexane, petroleum ether, chloroform, acetone and methanol extracts of leaves of Memecylon heyneayanum were subjected to a preliminary screening for antimicrobial activity against selected human pathogenic microorganisms. Three concentrations of the extracts were used $(100 \mu \mathrm{g} / \mathrm{ml}, 150 \mu \mathrm{g} / \mathrm{ml}$, and $200 \mu \mathrm{g} / \mathrm{ml})$ and higher concentration $200 \mu \mathrm{g} / \mathrm{ml}$ showed better inhibitory activity against pathogenic microbes. It was clear from the present results that Methanolic leaf extract had a broad spectrum of activity against all the tested microorganisms followed by acetone, chloroform, petroleum ether and hexane. Among these three concentrations of the extracts tested, the higher concentration $(200 \mu \mathrm{g} / \mathrm{ml})$ showed better antimicrobial activity. This tends to show that the active ingredients of the leaves are better extracted with methanol than with any other solvent. Since, nearly all of the identified compounds from plants active against microorganisms are aromatic or saturated organic compounds and they are most often obtained through initial ethanol or methanol extraction [12].

Jojireddy and Beenajose[13] reported, methanol extract of $S$. cuminithe leaf exhibited higher activity than the other extracts. In the current study, Methanolic extract $(18-26 \mathrm{~mm} / 50 \mu \mathrm{l}$ zone of inhibition), ethyl acetate showed $(14-20 \mathrm{~mm} / 50 \mu \mathrm{l})$, chloroform showed $(11-16 \mathrm{~mm} / 50 \mu \mathrm{l})$ and petroleum ether showed $(10-14 \mathrm{~mm} / 50 \mu \mathrm{l})$ extracts against various test organisms such as Bacillus cereus, Enterobacter faecalis, Salmonella paratyphi, Staphylococcus aureus, Escherichia coli, Proteus vulgaris, Klebsiella pneumoniae, Pseudomonas aeruginosa and Serratia marcescens. Chandrasekar[14]in which methanol extract of the aerial parts of Phyllanthus debilis exhibited antibacterial activity against both gram positive and gram negative bacteria.

Based on the previously discussed results, the methanolic extract has a stronger and broader spectrum of antimicrobial activities compared with the ethanol extracts, thus methanol was recommended for the extraction of the active antibacterial agents from $O$. basilicum. This result was in accordance with previous studies which reported that methanol was a better solvent for the more consistent extraction of antimicrobial substances from medicinal plants compared to other solvents such as water and ethanol $[15,16,17]$. The Hexane, Chloroform and Petroleum ether leaf extracts of Millettia peguensis exhibited antimicrobial activity against all the selected microorganisms. Among these three concentrations (100 $\mathrm{mg} / \mathrm{ml}, 150 \mathrm{mg} / \mathrm{ml}$ and $200 \mathrm{mg} / \mathrm{ml}$ ) of Hexane, Chloroform and Petroleum ether extract the higher concentration (200 $\mathrm{mg} / \mathrm{ml}$ ) showed higher inhibitory activity against all the tested microorganisms [18].

The leaves of Memecylon heyneayanum showed varying degrees of antimicrobial activity on the microorganisms tested. It is interesting to note that even crude extract of this plant showed prominent activity against various pathogenic bacteria where modern therapy has failed. Due to the emergence of the antibiotic resistant pathogens, plants are being looked upon as an excellent alternate to combat the spread of multi drug resistant microorganisms.

\section{Conclusions}

The results suggest that the leaf extracts of Memecylon heyneayanum as well as leaf methanol extract showed significant activity compare with other solvents against selected microorganisms. The activity of leaf extract was found to be quite comparable with the standard antibiotics screened under similar conditions. So they can be used as an external antiseptic in the prevention and treatment of bacterial infections caused by various pathogenic bacteria and fungi such as Gram-positive bacteria viz.Bacillus cereus, Staphylococcus aureus, Micrococcus mucilaginosus and gram-negative bacteria, Klebsiella pneumoniae, Pseudomonas aeuruginosa, Escherichia coli, and Klebsiella terrigena and fungal species Candida albicans, Candida glabrata and Candida sp. which have developed resistance to antibiotics. The incorporation of these samples into the drug formulations is also recommended. This study recommended that the methanolic leaf extracts of Memecylon heyneayanum can be used effective modern medicine to combat pathogenic microorganisms.

\section{REFERENCES}

[1] Cragg, G. M. and Newman. D. J. Medicinals for the millennia: the historical record. Ann N.Y Acad. Sci. 953, 3. 2001.

[2] Krisharaju, A.V., Rao, T.V. and Sundararaju, A. Assessment of bioactivity of Indian medicinal plants using Brine shrimp (Altenariasalania) lethality assay. Int. J. Appl. Sci. Engg. 2: 125- 134. 2005.

[3] World Health Organization (WHO) Traditional medicine. Fact sheet number 134. Revised May, 2003. Available on http/www.who.int/media centre fact sheet/fs/134. 2001.

[4] Manikandan G. Vimala Rani A., Divya C. and Ramasubbu R. GC-MS analysis of phytochemical constituents in the petroleum ether leaf extracts of Millettia peguensis. Int. Res. J. Pharm. 8(9):144-150. 2017.

[5] Srinivasan, D., Nathan, S., Suresh, T. and Perumalsamy,O. Antimicrobial activity of certain Indian medicinal plants used in folkloric medicine. J. Ethnopharmacol. 74:217-220. 2001.

[6] Jain, F., Mosotti, V., Bessiere, J.M., Dherbomez, M. and Viano, J. Antibactrial and antioxidant activities of Artemisia annua essential oil. Fitoterapia. 73 (6): 532-535. 2002.

[7] Sieradzki, K., Roberts, R.B., Haber, S.W. and Tomasz, A. The development of vancomycin resistance in a patient with 
Methicillin-resistant Staphylococcus aureus infection. $N$. Engl. J. Med. 340: 517-523. 1999.

[8] Sivu, AR., Pradeep, NS., Rameshkumar, K.B., Pandurangan, A.G. Evaluation of phytochemical, antioxidant and antimicrobial activities of MemecylonL. species from Western Ghats. Ind. J. of Nat. Prod. and Resources. 4(4): 363-370. 2013.

[9] Ignacimuthu, S. and Amalraj, T. Effect of bark extract of Myricanagi on diabetic rats; Solai Bulletin of Ethnopharmacology. 1: 43-46. 1998.

[10] Manikandan, G.; Pandiselvi, P.; Sobana, N.; Murugan, M. GC-MS analysis of chemical constituents in the methanolic tuber extract of Momordica cymbalaria Hook. F. Int. Res. J. Pharm. 10(1):135-140. 2019.

[11] Abubakar, E.M. Antibacterial potential of crude leaf extracts of Eucalyptus camaldulensis against some pathogenic bacteria. Afr. J. Pl. Sci. 4 (6): 202-209. 2008.

[12] Cowan, M. Plant products as antimicrobial agents. Clin. Microbiol. Rev. 12: 564-582. 1999.

[13] Joji Reddy, L. and Jose, B. Evalution of Antimicrobial and
Dpph Radical Rcavenging Activities of the Leaf Extracts and Leaf Essential Oil of Syzygium cummini L. from South India. Int. J. of Pharmacy and Pharmaceutical Sci. 358-361. 2013.

[14] Chandarashekar, K.S., Sathyanarayana. and Prasanna, K.S. Antimicrobial Activity of Phyllanthus debilis.Int. Res. J. of Pharmacy. 2 (6): 75-76. 2011.

[15] Ahmad, I., Mehmood, Z. and Mohammad, F. Screening of Some Indian Medicinal Plants for their Antimicrobial Properties. J. of Ethnophamacology. 62: 183-193. 1998.

[16] Cordell, G.A. Biodiversity and Drug Discovery a Symbiotic Relationship. Phytochemistry. 55: 463-480. 2000

[17] Elloff, J.N. Which Extract Should Be Used for the Screening and Isolation of Antimicrobial Components from Plants. $J$. Ethnopharmacology. 60: 1-8. 1998.

[18] Packiyalakshmi, D., Athilakshmi, P., Gayathri, S., Karthiga, P., ThiriBhuvaneswari, R. and Manikandan, G. Antimicrobial potential of different solvents leaf extract of Millettia peguensis against selected pathogens. The Pharma Innovation Journal. 6(10): 119-124, 2017. 